\author{
Е. А. Наумова \\ Кандидат экономических наук, доцент, \\ заведующий кафедрой бухгалтерского учета и аудита, \\ elenanaumova@mail.ru \\ Санкт-Петербургский государственный морской технический университет, \\ Санкт-Петербург, Россия

\begin{abstract}
Аннотация: Рассматриваются вопросы повышения достоверности информации о собственном капитале организации, ее раскрытия и представления в составе бухгалтерской (финансовой) отчетности в контексте принятия новых федеральных стандартов бухгалтерского учета и изменений требований регулятора. Обосновывается необходимость повышения информативности системы учета и отчетности собственного каптала, в том числе на основе международных стандартов финансовой отчетности. Анализируются пределы раскрытия информации, обусловленные внешними и внутренними факторами.
\end{abstract}

Ключевые слова: собственный капитал, уставный капитал, добавочный капитал, резервный капитал, нераспределенная прибыль (непокрытый убыток), достоверность бухгалтерской (финансовой) отчетности, государственный информационный ресурс, аудиторское заключение, бенефициарный собственник, транспорентность организаций.

\title{
Formation, disclosure and presentation of information on equity in conditions of increasing transparency of organizations
}

\author{
E. A. Naumova \\ Cand. Sci. (Econ.), Head of Dep., \\ elenanaumova@mail.ru \\ Saint Petersburg State Marine Technical University, \\ Saint Petersburg, Russia
}

\begin{abstract}
The issues of increasing the reliability of information about the organization's own capital, its presentation and disclosure as part of the financial (accounting) statements in the context of the adoption of new federal accounting standards and changes in the requirements of the regulator are considered. The necessity of increasing the information content of the system of accounting and reporting of equity, including on the basis of international financial reporting standards, is substantiated. The limits of information disclosure due to external and internal factors are analyzed.
\end{abstract}

Keywords: equity, authorized capital, additional capital, reserve capital, retained earnings (uncovered loss), reliability of financial (accounting) statements, state information resource, auditor's report, beneficial owner, transportability of organizations.

Государством взят курс на повышение транспорентности или открытости бизнеса. Информационная прозрачность компаний является неотъемлемым фактором развития экономики и создания благоприятного инвестиционного и делового климата. При этом она складывается из нескольких составляющих, таких как финансовая, правовая, технологическая, управленческая и социальная открытость, каждая из которых может рассматриваться как самостоятельно, так и во взаимосвязи с остальными.

Финансовая открытость компании регламентируется системой нормативного регулирования бухгалтерского учета и отчетности, предоставляемой внешним пользователям и размещае- 
мой на доступных информационных ресурсах. При этом, согласно действующим бухгалтерским стандартам, недостаточно просто соблюдения всех правил ведения учета и составления отчетности, то есть того, чтобы отчетность не нарушала этих требований. Немаловажным становится также максимально полное раскрытие в отчетности информации о хозяйствующем субъекте в целях создания благоприятных условий для внешних заинтересованных пользователей в процессе принятия ими решений по возможному взаимодействию с этим субъектом. Пределы раскрытия информации определяются с одной стороны, требованиями стандартов, с другой стороны - профессиональным суждением составителей отчетности, поскольку представление подробной информации о субъекте может сделать компанию уязвимой для конкурентов.

Происходящая в настоящее время активная перестройка национальной системы финансового учета в соответствии с реализацией Программы разработки федеральных стандартов бухгалтерского учета (далее - ФСБУ), утвержденной Минфином России, требует переосмысления применяемых способов и методов ведения учета и составления отчетности, адаптации их к изменяющимся подходам в отношении идентификации, оценки, раскрытия информации об объектах учета и фактах хозяйственной жизни организаций. Это подтверждает актуальность исследований современного состояния вопросов формирования и раскрытия информации о собственном капитале организации в бухгалтерской (финансовой) отчетности, выявления наиболее проблемных из их числа и поиска наилучших путей решения таких вопросов.

\section{Сущность собственного капитала организации как объекта финансового (бухгалтерского) учета}

Собственный капитал является ключевой категорией бухгалтерского учёта, определяет финансовую устойчивость организации и эффективность её деятельности. Выделяют три основных подхода к формулированию сущностной трактовки капитала: экономический, бухгалтерский и учетно-аналитический.

Экономический подход базируется на концепции физического капитала, при которой капитал рассматривается как совокупность ресурсов, являющихся источником доходов предприятия. При этом он подразделяется на реальный (физический) и финансовый (монетарный) капитал. Реальный капитал связан с материально-вещественными ресурсами организации (основными средствами, запасами и пр.). Финансовый капитал - это денежные средства, ценные бумаги. В соответствии с этой концепцией капитал представляет собой активы предприятия, его стоимостная оценка исчисляется как итог актива бухгалтерского баланса (валюта баланса).

Бухгалтерский подход основан на концепции финансового капитала. В этом случае капитал рассматривается с позиций источников приобретения ресурсов предприятия. Капитал также трактуется как интерес собственников предприятия в его активах, в этом случае он выступает синонимом собственного капитала организации, а его величина рассчитывается как разность между суммой активов предприятия и величиной его обязательств. При этом подходе капитал - это основа для создания предприятия, источник активов и покрытия обязательств, обеспечивающий непрерывное функционирование предприятия и максимизацию прибыли.

Учетно-аналитический подход (разновидность бухгалтерского) основан на модификации концепции финансового капитала. В соответствии с этим подходом капитал рассматривают с позиции инвесторов, когда капитал, как источник ресурсов предприятия, включает в себя помимо собственных средств, также привлеченные долгосрочные и краткосрочные источники финансирования и может исчисляться как итог пассива баланса.

Таким образом, бухгалтерский подход к сущности капитала дает возможность рассматривать капитал предприятия и как активы, ресурсы предприятия, и как источник формирования этих активов. Такой подход отражается в основной форме бухгалтерской отчетности - бухгалтерском балансе.

Категорию собственного капитала можно считать всесторонне изученной в трудах российских экономистов Ю.А. Бабаева, А.С. Бакаева, П.С. Безруких, В.Г. Гетьмана, Е.А. Ендовицкого, В.В. Ковалева, М.И. Кутера, В.Ф. Палий, Я.В. Соколова, А.Д. Шеремета, Л.З. Шнейдмана и др. 
Анализируя представленные определения, можно подытожить, что сущность собственного капитала, как учетной категории, сводится к следующему:

- экономическая сущность данной категории, как составной части капитала, заключается в том, что собственный капитал - это средства, вложенные собственником в предприятие, способные приносить прибыль;

- юридическая сущность собственного капитала заключается в том, что это обязательство предприятия перед собственником, выраженное в виде активов, оставшихся после вычета остальных обязательств предприятия. Это обязательство погашается при ликвидации предприятия; - расчетная величина собственного капитала равна чистым активам предприятия. ${ }^{1,2}$

В составе собственного капитала выделяют две основные составляющие: инвестированный капитал, т.е. капитал, вложенный собственниками в организацию, и накопленный капитал - капитал, созданный в организации сверх того, что было первоначально авансировано собственниками (рис. 1).

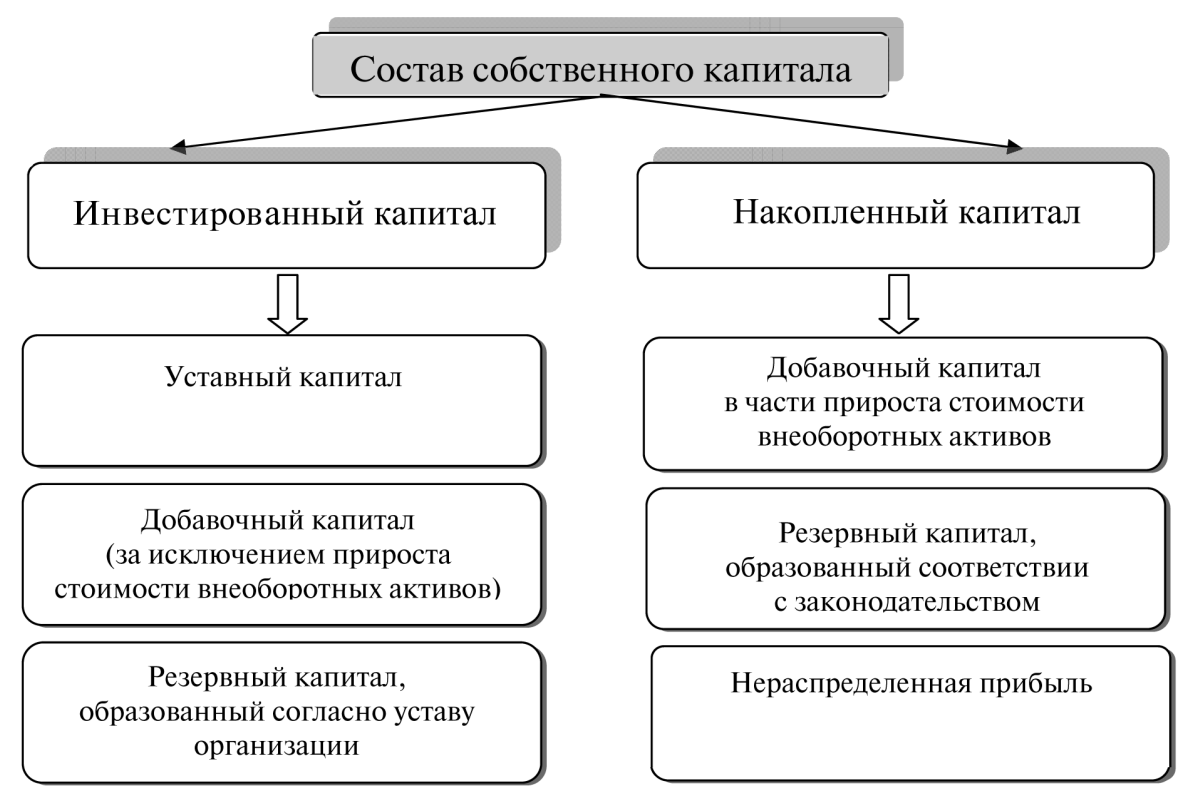

Рис. 1. Состав собственного капитала организаций ${ }^{3}$

Открытость бизнеса предполагает предоставление заинтересованным пользователям достоверной информации, составленной согласно требованиям, одинаково понимаемыми и принимаемыми сторонами процесса. Поэтому роль государственного регулирования порядка ведения учета и определения допустимых границ самостоятельности хозяйствующих субъектов при выборе способов и методов ведения учета становится решающей.

Необходимо отметить, что в российской нормативной базе по бухгалтерскому учету (далее РСБУ) определение капитала или собственного капитала не регламентировано. Закон № 402-Ф3 «О бухгалтерском учете» также не рассматривает собственный капитал в качестве отдельного объекта бухгалтерского учета.

\footnotetext{
${ }^{1}$ Ендовицкий Е.А., Дохина Ю.А. Экономическая сущность и правовое регулирование капитала организации. Социально-экономические явления и процессы. 2010 г. № 5 (021). С. 12-16.

${ }^{2}$ Евстафьева Е.М. Теоретические аспекты исследования десиниции «Капитал» с позиции эволюции бухгалтерского учета, экономический журнал «Вестник АГУ». 2015 г. № 3 (165).

3 Положение по ведению бухгалтерского учета и бухгалтерской отчетности в РФ, утв. приказом Минфина РФ № 34н от 29.07.1998. (ред. от 11.04.2018).//URL: http:// http://www.consultant.ru/document/cons_doc_LAW_20081/Загл. с экрана.
} 
Согласно концептуальным основам международных стандартов (далее - МСФО), капитал организации -это остаточная доля участия в активах организации после вычета всех ее обязательств, то есть фактически это чистые активы. ${ }^{4}$

Как и в РСБУ, в МСФО нет отдельного стандарта, посвященного вопросам признания и отражения в отчетности капитала компании и его элементов, при этом отдельные аспекты учета капитала рассматриваются в соответствующих МСФО.

В этой связи бухгалтерский учет собственного капитала должен быть организован экономическим субъектом исходя из действующей четырехуровневой системой нормативно-правового регулирования учета и отчетности в Российской Федерации, которая лежит в основе построения системы учета каждой организации. Задавая общие принципы, способы и возможные методы учета, она при этом предусматривает самостоятельность организаций при принятии решений по выбору и обоснованию конкретных методов и способов учета, отвечающих потребностям, размерам и масштабу бизнеса, стратегическим целям и тактическим задачам его развития. В этой связи велико значение профессионального мнения бухгалтеров, формирующих такую систему учета и отчетности для конкретного экономического субъекта, а также руководителей, ответственность которых за организацию системы бухгалтерского учета закреплена законодательно.

\section{Создание системы учета собственного капитала организаций}

Действующая система учета собственного капитала в РФ, по мнению многих исследователей, не является достаточно информативной, чтобы удовлетворить растущие запросы внешних пользователей, поскольку она основана на данных об уже свершившихся фактах хозяйственной жизни и не дает достоверного представления о перспективах роста стоимости капитала организации, величине и структуре будущих денежных потоков ${ }^{5}$.

ФСБУ экономическим субъектам предписано ведение учета в разрезе установленных элементов собственного капитала, таких как уставный (складочный) капитал, добавочный капитал, резервный капитал, нераспределенная прибыль (непокрытый убыток) и прочие резервы. (рис.2)

Учет каждой составляющей собственного капитала определяется их экономической сущностью, предназначением, задачами и функциями, а также особенностями совершаемых операций. В целом, систему учета собственного капитала можно считать сформированной и не претерпевшей в последние годы существенных изменений, за исключением новаций о отношении отдельных его элементов.

Уставный капитал - это начальный капитал, необходимый для осуществления финансовохозяйственной деятельности организации, который вносят учредители. Он представляет собой совокупность вкладов учредителей в денежном выражении и не может быть меньше суммы, установленной законодательством. Название, структура уставного капитала и порядок его формирования зависит от организационно-правовой формы хозяйствующего субъекта.

С бухгалтерской точки зрения он представляет собой имущественные и денежные ресурсы, инвестированные участниками, имеющие стоимостную оценку, необходимые для финансового и материального обеспечения первого хозяйственного цикла созданного юридического лица.

Информация о состоянии и движении уставного капитала (складочного капитала) организации представлена на бухгалтерском счете 80 «Уставный капитал», кредитовое сальдо должно соответствовать размеру уставного капитала, который зафиксирован в учредительных документах.

Аналитический учет по счету 80 «Уставный капитал» организуется так, чтобы можно было обеспечить формирование информации по учредителям организации, стадиям формирования капитала и видам акций (для акционерных обществ).

\footnotetext{
${ }^{4}$ Международный стандарт финансовой отчетности (IAS) 1 «Представление финансовой отчетности» (введен в действие на территории РФ Приказом Минфина России от 28.12.2015 № 217н) (ред. от 05.08.2019)//URL: http:// www.consultant.ru/document/cons_doc_LAW_193588 - Загл с экрана.

${ }^{5}$ Курышева Т.Н. Бухгалтерский учет собственного капитала экономического субъекта на современном этапе развития экономики. EUROPEAN RESEARCH. - Сборник статей II Международной научно-практической конференции. - Пенза: Изд-во Наука и Просвещение. 2016. С. 37-46.
} 
Для повышения информативности сведений о движении уставного капитала в акционерных обществах рекомендуется открытие как минимум трех субсчетов к счету 80 «Уставный капитал», для обособленного учета объявленного, подписного и оплаченного капитала. В организациях других организационно-правовых форм собственности достаточно двух субсчетов, для отражения зарегистрированного и оплаченного капитала. ${ }^{6}$

Резервный капитал может создаваться как в соответствии с требованиями законодательства, так и по решению учредителей Обязательность его создания предусмотрена только для акционерных обществ, в минимальном размере не менее 5\% от величины уставного капитала; для организаций с иностранными инвестициями - не менее $25 \%$; в производственных кооперативах - не менее $10 \%$ паевого фонда. Назначение резервного капитала - покрытие убытков общества, а также для погашения облигаций общества и выкупа акций общества в случае отсутствия иных средств.

Создание резервного капитала предусмотрено за счет чистой прибыли. Для акционерных обществ размер ежегодных отчислений в резервный капитал не может быть ниже 5\% от чистой прибыли организации за отчетный период. Его использование осуществляется на цели, предусмотренные уставом организации и законодательством.

Для учета резервного капитала предназначен счет 82 «Резервный капитал».

Учет резервного капитала согласно МСФО следует признать более информативным, поскольку предусматривает его деление на чистые и отвлеченные резервы. К чистым резервам относится резервный фонд, который сформирован из нераспределенной прибыли организации и не требует корректировки. Информация об отвлеченных резервах согласно МСФО представлена двумя составляющими: затратными и оценочными резервами, что позволяет внешним пользователям определить степень юридических и других ограничений на распределение или какое-либо использование организацией своего капитала. ${ }^{7}$

В российском учете раскрытие информации об оценочных резервах предусмотрено в составе заемных средств (долгосрочных и краткосрочных обязательств).

Добавочный капитал выступает источником увеличения стоимости имущества организации. Счет 83 «Добавочный капитал» обеспечивает формирование информации по источникам образования и направлениям использования средств.

Одна из составляющих добавочного капитала - эмиссионный доход. Современная практика расширила содержание статьи эмиссионного дохода, которая может применяться не только акционерными обществами. По этой же статье следует отражать:

- оплату своих долей участниками общества с ограниченной ответственностью в сумме, превышающей номинал долей (например, при внесении имущества неденежными средствами);

- сумму НДС, который может быть зачтён в случае получения в уставный капитал немонетарных активов и др.

Возможность признания данных сумм в составе эмиссионного дохода подтверждается позицией Минфина, который рекомендует принимать их к учёту, используя порядок, установленный для учёта суммы разницы между продажной и номинальной стоимостью акций, вырученной в процессе формирования уставного капитала акционерного общества. ${ }^{8}$

Существенные новации внесены в порядок формирования добавочного капитала в части сумм переоценки внеоборотных активов в связи с введением в действие новых ФСБУ, построенных на принципах МСФО.

\footnotetext{
${ }^{6}$ Кыштымова Е.А. Методологические подходы к формированию учетно-аналитических подсистем для управления инвестированным капиталом предприятий. Фундаментальные исследования. - Москва: ООО «Издательский дом «Академия естествознания», № 2-1, 2016. С.169-174.

7 Лысюк Е.Ю., Тхаркахова И.Г. Резервный капитал в трактовке МСФО. Стратегические направления развития науки, образования, технологий. Сборник научных трудов по материалам международной научно-практической конференции. в 4-х частях / Под общей редакцией Ткачевой Е.П. 2017 ООО «Агентство перспективных научных исследований». - Белгород, 2017. С. 86-89.

${ }^{8}$ Боташева Л.С., Чагарова Д.Б. Бухгалтерский учет формирования добавочного капитала за счет эмиссионного дохода. Наука и образование сегодня. № 4(27), 2018. С. 39-41.
} 
Так, согласно ФСБУ 6/2020 «Основные средства»организации теперь имеют право отражать объекты основных средств по переоцененной стоимости после их первоначального признания. ${ }^{9}$ При этом их стоимость должна регулярно переоцениваться, чтобы она была равна или существенно не отличалась от его справедливой стоимости, определяемой согласно МСФО (IFRS) 13 «Оенка справедливой стоимости». В отличие от ранее действующего порядка переоценки, который осуществлялся пропорциональным пересчетом (переоценивается первоначальная стоимость и амортизация), появился также способ переоценки остаточной стоимости (разницы первоначальной стоимости и накопленной амортизации на дату переоценки).

Сумма переоценки по-прежнему относится на добавочный капитал, но теперь предусмотрены два способа списания переоценки:

- единовременно при списании переоцененного объекта основных средств;

- по мере начисления амортизации по такому объекту.

Аналогично последующая переоценка с отражением результатов в составе добавочного капитала предусмотрена МСФО (IFRS) 38 «Нематериальные активы» и в отношении объектов нематериальных активов.

Можно констатировать, что с введением в действие новых ФСБУ, предусматривающих обязательность последующей оценки внеоборотных актив согласно МСФО, информация о добавочном капитале организаций становится более достоверной и полнее раскрывающей сведения об источниках увеличении стоимости имущества организации.

Нераспределенная прибыль (непокрытый убыток) предприятия - это чистая прибыль, накопленная за все годы существования предприятия, которая не распределена на дивиденды. Фактически, она создает основу собственного капитала любой организации.

Основным источником пополнения нераспределенной прибыли (покрытия убытка) является чистая прибыль текущего года. Распределение (использование) накопленной прибыли осуществляется на основании решений учредителей (собственников). Все операции отражаются на счете 84 «Нераспределенная прибыль (непокрытый убыток)».

Перечень направлений расходования чистой прибыли открытый, причем большинство их специальным образом прописано в законодательстве, в соответствии с организационно-правовой формой хозяйствования (в первую очередь, согласно Федеральному закону № 208-Ф3 «Об акционерных обществах» и Федеральному закону № 14-Ф3 «Об обществах с ограниченной ответственностью»).

При всем многообразии подходов к распределению прибыли, для всех организаций характерны одни и те же принципы распределения прибыли - это направление ее:

- на накопление, т. е. на развитие компании (образование и пополнение резервных и инвестиционных фондов, вложение в уставные капиталы других компаний, финансовые инвестиции);

- на потребление, т.е. распределенная прибыль (выплата дивидендов, обеспечение социальной и материальной поддержки персонала и др.).

Исследователи отмечают отсутствие единого методологического подхода к организации учета использования нераспределенной прибыли. С одной стороны, подобная ситуация не противоречит так называемой собственнической концепции учета, с точки зрения которой прибыль, остающаяся в распоряжении собственников, может использоваться по их усмотрению, и за ее расходование они не должны отчитываться. С другой стороны, отсутствие системного учета расходования чистой прибыли порождает ситуацию, при которой часть прибыли, отражаемая в бухгалтерской отчетности, уже фактически израсходована, а другая часть - остается в распоряжении организации. Отсутствие необходимой аналитики снижает объективность экономических решений пользователей относительно имущественного и финансового положения экономического субъекта. ${ }^{10}$

\footnotetext{
${ }_{9}^{9}$ Федеральный стандарт бухгалтерского учета «Основные средства», утв. приказом Минсина России от 17.09.2020 № 204н (ФСБУ 6/2020) / /URL: http:/ / www.consultant.ru/document/cons_doc_LAW_365338/ - Загл с экрана. 10 Поленова С.Н. Вопросы регулирования бухгалтерского учета нераспределенной прибыли. Аудитор. Номер 3. Год: 2018. С. 27-33.
} 
В рамках решения обозначенной проблемы целесообразна организация системы аналитического учета нераспределенной прибыли, обеспечивающей получение развернутой информации о формировании и использовании нераспределенной прибыли (непокрытого убытка) по направлениям ее использования, например, в рамках отдельных субсчетов.

ПБУ 1/2008 «Учетная политика организации» предусмотрена самостоятельная разработка способа ведения учета, если по конкретному вопросу этот способ не установлен в федеральных стандартах. ${ }^{11}$ При этом регламентировано руководствоваться законодательством о бухгалтерском учете с использованием последовательно следующих источников:

- МСФО;

- Положений федеральных или отраслевых стандартов бухгалтерского учета по аналогичным

или связанным вопросам;

- рекомендаций в области бухгалтерского учета.

Это значит, что нормы МСФО являются предпочтительными по отношению к отечественным стандартам и разработку новых способов ведения учета, в том числе и собственного капитала, следует осуществлять исходя из международных норм.

Каждой организации необходимо предусмотреть в учетной политике порядок синтетического и аналитического учета элементов собственного капитала, предусматривающий детализацию информации о его составе, источниках формирования и направлениях расходования, в интересах как собственников организации, так и внешних пользователей.

\section{Представление информации о собственном капитале организации}

Информация, содержащаяся в системе бухгалтерского учета организаций, содержит значительный объем сведений, которые могут быть отнесены к коммерческой тайне, поэтому единственным доступным источником о собственном капитале организаций для внешних пользователей выступает бухгалтерская (финансовая) отчетность.

С принятием в 2010 году нового Закона «О бухгалтерском учете» существенно повысилась транспорентность организаций, благодаря установлению обязательности участия в формировании государственного информационного ресурса бухгалтерской отчетности (ГИРБО), представляющего собой совокупность бухгалтерской (финансовой) отчетности экономических субъектов и аудиторских заключений о ней. ${ }^{12}$

Целью его создания является повышение открытости организаций, обеспечение доступа к бухгалтерской отчетности всем заинтересованным пользователям.

В составе бухгалтерской финансовой отчетности организаций закреплены две основных формы отчетности: бухгалтерский баланс и отчет о финансовых результатах, а также приложения к ним в составе отчета об изменениях капитала, отчета о движении денежных средств и пояснений.

Состав и содержание показателей названных форм отчетности конкретизируют ПБУ 4/99 «Бухгалтерская отчетность организации» ${ }^{13}$ и Положение по ведению бухгалтерского учета и бухгалтерской отчетности в Российской Федерации, сами формы отчетности утверждены приказом Минфина России от 02.07.2010 № 66н. ${ }^{14}$

Собственному капиталу посвящен раздел III «Капитал и резервы» пассива бухгалтерском баланса, содержащий сведения о структуре и величине капитала за три последовательных года, включая отчетный год.

\footnotetext{
${ }^{11}$ Положение по бухгалтерскому учету «Учетная политика организации», утв. приказом Минфина РФ № 106н от 06.10.2008 (ПБУ 1/2008) (ред. от 07.02.2020)//URL: http://www.consultant.ru/document/cons_doc_LAW_ $81164 /-$ Загл. с экрана.

${ }^{12}$ Статья 18, п. 5 Федерального закона «О бухгалтерском учете» № 402-ФЗ от 06.12.2011. (ред. от 26.07.21) // URL: http://www.consultant.ru/document/cons_doc_LAW_122855/- Загл. с экрана.

${ }^{13}$ Положение по бухгалтерскому учету «Бухгалтерская отчетность организации» ПБУ 4/99 (утв. приказом Минфрина РФ № 43н от 06.07.1999). (ред. от 08.11.2010, с изм. от 29.01.2018) // URL: http://www.consultant.ru/ document/cons_doc_LAW_18609/-Загл. с экрана.

${ }^{14}$ О формах бухгалтерской отчетности организаций, утв. Приказом Минсина РФ № 66н от 02.07.2010. (ред. от 19.04.2019)//URL: http://www.consultant.ru/document/cons_doc_LAW_103394/ - Загл. с экрана.
} 
Отчет о финансовых результатах содержит сведения о доходах и расходах организации и различных показателях прибыли, в том числе чистой прибыли, которые необходимы для анализа порядка формирования нераспределенной прибыли (непокрытого убытка) отчетного года.

Главным отчетным документом по раскрытию информации о собственном капитале организации выступает Отчет об изменениях капитала, который состоит их трех разделов.

В первом разделе «Движение капитала» отражается информация, детализирующая показатели о динамике (уменьшении и увеличении) капитала, в разрезе основных элементов собственного капитала. Второй раздел «Корректировки в связи с изменением учетной политики и исправлением ошибок» содержит информацию о производимых корректировках нераспределенной прибыли (непокрытого убытка) в связи с изменениями в учетной политике (согласно ПБУ 1/2008 «Учетная политика организации») и исправлениями выявленных существенных ошибок, которые производятся ретроспективным методом (согласно ПБУ 22/2010 «Исправление ошибок в бухгалтерском учете и отчетности).

Третий раздел сдержит показатели чистых активов организации, расчет которых производится на основании Приказа Минфина России. ${ }^{15}$ Данный показатель является значимым инструментом при решении ряда финансовых вопросов в деятельности экономического субъекта и его взаимоотношений с собственником.

Фактически показатель чистых активов означает остаточный интерес собственников в капитале организации, разницу между активам организации и требований (обязательств) к этим активам. При этом, к расчету не принимаются:

- объекты бухгалтерского учета, учитываемые организацией на забалансовых счетах;

- часть активов в виде дебиторской задолженности собственников по взносам в уставный капитал (по оплате акций);

- обязательства организации в виде доходов будущих периодов, признанных организацией, например, в связи с получением государственной помощи или в связи с безвозмездным получением имущества.

Если по окончании финансового года стоимость чистых активов оказывается меньше величины уставного капитала, организации необходимо в течение шести месяцев уменьшить его размер до величины чистых активов, в противном случае - ликвидировать организацию.

В пояснениях к бухгалтерскому балансу и отчету о финансовых результатах согласно требованиям РСБУ и МСФО организации должны раскрывать сведения о произошедших изменениях в капитале, а акционерные общества - также информацию о составе и структуре акционерного капитала и произведенных операциях с акциями. При этом в МСФО предусмотрено более подробное раскрытие информации о характере и назначении каждого вида резерва, об акциях акционерного общества и пр.

Организация может самостоятельно принять решение о дополнительном раскрытии информации о собственном капитале в бухгалтерской (финансовой) отчетности согласно требованиям МСФО.

Достоверность информации, представленной в ГИРБО, обеспечивается не только эффективной системой учета самих хозяйствующих субъектов, но и проверкой такой отчетности внешним независимым экспертом - аудитором. Публикация отчетности предусмотрена одновременно с соответствующим аудиторским заключением, которое, начиная с отчетности за 2018 год, должно составляться согласно требованиям международных стандартов аудита.

Операции с собственным капиталом организации, в силу особой их значимости для оценки финансового положения организации, как правило, подлежат сплошной, а не выборочной аудиторской проверке, при которой проверяются все совершенные за отчетный период операции.

При сборе аудиторских доказательств, подтверждающих достоверность информации о собственном капитале организации, аудиторы руководствуются не только количественной характе-

\footnotetext{
15 Порядок определения стоимости чистых активов, утв. Приказом Минфина РФ №84н от 20.08.2014 (ед. от 27.11.2020)//URL: http://www.consultant.ru/document/cons_doc_LAW_169895/ - Загл. с экрана.
} 
ристикой категории сушественности (то есть предельным значением совершенной ошибки), но и качественной характеристикой, на основе которой оценивается существенность отклонений в порядке совершенных операций с собственным капиталом от требований действующих нормативных актов, вне зависимости от стоимостной величины таких отклонений. Значительное внимание аудитором должно быть уделено также представленным пояснениям к отчетности, в которых должна быть раскрыта необходимая информация согласно требованиям ФСБУ.

В случае, если аудитором представлено немодифицированное заключение, это означает, что бухгалтерская (финансовая) отчетность не содержит существенных искажений и во всех существенных отношениях достоверно отражает финансовое положение аудируемого лица и результаты его финансовой деятельности в соответствии с действующими правилами финансовой отчетности. В полной мере это относится и к содержащейся в отчетности информации о собственном капитале организации.

В случае выявления существенных искажений отчетности, аудитор формирует модифицированные заключения: мнение с оговоркой, отрицательное мнение, отказ от выражения мнения.

Выбор вида заключения зависит от характера обстоятельств, ставших причиной для модификации положительного мнения об отчетности, а также степени распространения влияния выявленных искажений на отчетность. Предоставление любой формы модифицированного аудиторского заключения предусматривает описание обстоятельств, ставших основанием для выдачи соответствующей модификации. ${ }^{16}$

В целом, формируемый в настоящее время ГИРБО предоставляет уникальные возможности для внешних пользователей в части получения необходимой информации о собственном капитале организации, а также экспертного аудиторского заключения о степени ее достоверности. Начиная с мая 2020 года запущен интернет-сервис, позволяющий бесплатно получить информацию о бухгалтерской (финансовой) отчетности любой организации, в том числе получить экземпляр отчетности, подписанный электронной подписью ФНС. Предусмотрено также платное абонентское обслуживание, по которому пользователи имеют возможность доступа к ежемесячно обновляемой базе бухгалтерской отчетности в том формате, в котором она поступает в ФНС. Такая развернутая информация может быть полезна для мониторинга и масштабной аналитики финансовой информации, содержащейся в отчетности различных организаций.

По мере накопления опыта формирования и последующего использования сведений из ГИРБО, повышения ответственности хозяйствующих субъектов за представленные в нем сведения, его эффективность и, как следствие, значимость для принятия решений разумными пользователями будет возрастать.

\section{Раскрытие информации о бенефициарных владельцах}

По мере развития системы регулирования бухгалтерского учета РФ и сближения ее с МСФО у организаций появляются дополнительные обязанности по раскрытию сведений в бухгалтерской финансовой отчетности.

Так, начиная с 2016 года организации должны раскрывать в пояснениях к бухгалтерской отчетности информацию о своих бенефициарных владельцах, согласно требований Федерального закона № 115-Ф3 от 07.08.2001 «О противодействии легализации (отмывании) доходов, полученных преступным путем, и финансированию терроризма»). ${ }^{17}$

Бенефициарный собственник- это физическое лицо, которое прямо или через третьих лиц владеет организацией (имеет более $25 \%$ в уставном капитале) или имеет возможность контролировать ее действия.

\footnotetext{
${ }^{16}$ Международный стандарт аудита 705 (пересмотренный) «Модифицированное мнение в аудиторском заключении» (введен в действие на территории Российской Федерации Приказом Минфина России от 09.01.2019 № 2н) // URL: http://www.consultant.ru/document/cons_doc_LAW_317413/- Загл. с экрана.

${ }^{17}$ Федеральный закон «О противодействии легализации (отмывании) доходов, полученных преступным путем, и финансированию терроризма» № 115-ФЗ от 07.08.2001. (ред. от 02.07.2021)//URL: http://www.consultant.ru/ document/cons_doc_LAW_32834/- Загл. с экрана.
} 
При раскрытии информации о бенефициарных владельцах указываются сведения, позволяющие их однозначно идентифицировать. Если в течение отчетного периода осуществлялись операции с бенефициаром, то в бухгалтерской отчетности дополнительно раскрывается информация о них согласно требований РСБУ и МСФО.

Информацию о бенефициарных владельцах обязаны запрашивать и аудиторы при формировании аудиторского заключения, подтверждающего достоверность бухгалтерской отчетности организаций, в том числе, касающейся информации о собственном капитале организации и его владельцах. ${ }^{18}$

Раскрытие информации о бенефициарных владельцах повышает прозрачность деятельности организаций, но при этом делает компании уязвимыми к санкциям, поэтому в регламентированных случаях она освобождается от выполнения соответствующих обязанностей. Так, например, в рамках проведения аудиторских проверок, организация имеет право не представлять сведения о своих бенефициарных владельцах аудиторской компании, которая находится под прямым или косвенным контролем иностранного гражданина. ${ }^{19}$

\section{Выводы}

Следует отметить наличие в российском учете развитой многоуровневой системы нормативного регулирования порядка формирования и раскрытия информации о собственном капитале экономических субъектов. Данная система активно развивается в направлении сближения с международными стандартами в соответствии с действующей Программой развития ФСБУ. Организации должны самостоятельно сформировать систему учета, максимально релевантную организационно-правовой форме, особенностям и масштабу бизнеса, целям и задачам формирования информации о собственном капитале. При этом в случае отсутствия необходимых способов решения задач в РСБУ следует руководствоваться, в первую очередь, нормами международных стандартов, даже если по действующему законодательству организация не обязана формировать отчетность в соответствии с МСФО.

Создаваемый в настоящее время ГИРБО является серьезным шагом в направлении повышения открытости информации о собственном капитале организаций. Ее значимость для целей принятия управленческих решений пользователями определяется полнотой и достоверностью предоставленных организациями сведений, а также качеством сформированных аудиторских заключений. ФСБУ допускают раскрытие в отчетности информации в ограниченном объеме в отношении сведений, которые обуславливают потери экономического характера, урон деловой репутации самой организации, ее контрагентов или взаимосвязанных сторон. ${ }^{20}$ Применительно к собственному капиталу это, в первую очередь, относится к раскрытию информации о бенефициарных владельцах организации.

В условиях повышения транспорентности бизнеса, каждый экономический субъект, исходя из особенностей хозяйствования, должен сформировать обоснованную систему показателей и сведений, подлежащих раскрытию в бухгалтерской финансовой отчетности относительно собственного капитала, с одной стороны, максимально полно характеризующих его в интересах внешних заинтересованных пользователей, с другой стороны, не допускающих возможные бизнеспотери от использования такой информации третьими лицами. Действующие в РФ механизмы и внедряемые цифровые технологии по созданию и использованию единых информационных ресурсов со сведениями о финансовой отчетности экономических субъектов должны способствовать эффективному решению поставленных задач.

\footnotetext{
${ }^{18}$ Наумова Е.А. Раскрытие в отчетности информации о конечных бенефициарах организации и ее аудиторское подтверждение. Актуальные проблемы учета, анализа и аудита: материалы X Юбилейной региональной научнопрактической конференции. - СПб.: Изд-во СПбГМТУ, 2020. С. 72-77.

19 Постановление Правительства РФ от 19.04.2021 № 622 «Об ограничениях на предоставление информации и документации аудиторской организации, индивидуальному аудитору» // URL: http://www.consultant.ru/ document/cons_doc_LAW_382679/-Загл. с экрана.

${ }^{20}$ Инфрормационное сообщение Минфина России от 24.02.2021 № ИС-учет-32 «Установлены особенности раскрытия информации в бухгалтерской отчетности» //URL: http://www.consultant.ru/document/cons_doc_LAW_ $377859 /-$ Загл. с экрана.
} 


\section{Список литературы}

1. Федеральный закон «О бухгалтерском учете» № 402-Ф3 от 06.12.2011. (ред. от 26.07.21) . URL: http:// www.consultant.ru/document/cons_doc_LAW_122855/.

2. Федеральный закон «О противодействии легализации (отмывании) доходов, полученных преступным путем, и финансированию терроризма» № 115-Ф3 от 07.08.2001. (ред. от 02.07.2021). URL: http://www.consultant.ru/document/cons_doc_LAW_32834/.

3. Постановление Правительства РФ от 19.04.2021 № 622 «Об ограничениях на предоставление информации и документации аудиторской организации, индивидуальному аудитору». URL: http:// www.consultant.ru/document/cons_doc_LAW_382679/.

4. Информационное сообщение Минфина России от 24.02.2021 № ИС-учет-32 «Установлены особенности раскрытия информации в бухгалтерской отчетности». URL: http://www.consultant.ru/ document/cons_doc_LAW_377859/.

5. Международный стандарт финансовой отчетности (IAS) 1 «Представление финансовой отчетности» (введен в действие на территории РФ Приказом Минфина России от 28.12.2015 № 217н) (ред. от 05.08.2019). URL: http://www.consultant.ru/document/cons_doc_LAW_193588/.

6. Международный стандарт аудита 705 (пересмотренный) «Мдифицированное мнение в аудиторском заключении» (введен в действие на территории Российской Федерации Приказом Минфина России от 09.01.2019 № 2H). URL: http://www.consultant.ru/document/cons_doc_LAW_317413/.

7. Положение по ведению бухгалтерского учета и бухгалтерской отчетности в РФ, утв. приказом Минфина РФ № 34н от 29.07.1998. (ред. от 11.04.2018). URL: http:// http://www.consultant.ru/document/ cons_doc_LAW_20081/.

8. Положение по бухгалтерскому учету «Учетная политика организации», утв. приказом Минфина РФ № 106н от 06.10.2008 (ПБУ 1/2008) (ред. от 07.02.2020). URL: http://www.consultant.ru/document/ cons_doc_LAW_81164/.

9. Положение по бухгалтерскому учету «Бухгалтерская отчетность организации» ПБУ 4/99 (утв. приказом Минфина РФ № 43н от 06.07.1999). (ред. от 08.11.2010, с изм. от 29.01.2018). URL: http:// www.consultant.ru/document/cons_doc_LAW_18609/.

10. Федеральный стандарт бухгалтерского учета «Основные средства», утв. приказом Минфина России от 17.09.2020 № 204н (ФСБУ 6/2020).URL: http://www.consultant.ru/document/cons_doc_LAW_365338.

11. О формах бухгалтерской отчетности организаций, утв. Приказом Минфина РФ № 66н от 02.07.2010. (ред. от 19.04.2019). URL: http://www.consultant.ru/document/cons_doc_LAW_103394/.

12. Порядок определения стоимости чистых активов, утв. Приказом Минфина РФ № 84н от 20.08.2014 (ед. от 27.11.2020). URL: http://www.consultant.ru/document/cons_doc_LAW_169895/.

13. Евстафьева Е.М. Теоретические аспекты исследования дефиниции «Капитал» с позиции эволюции бухгалтерского учета, экономический журнал «Вестник АГУ». 2015. № 3 (165).

14. Ендовицкий Е.А., Дохина Ю.А. Экономическая сущность и правовое регулирование капитала организации. Социально-экономические явления и процессы. 2010. № 5 (021). С. 12-16.

15. Канашевский В.А. Концепция бенефициарной собственности в российской судебной практике (частноправовые аспекты). Журнал российского права. 2016. № 9 (237). С. 27-38.

16. Курышева Т.Н. Бухгалтерский учет собственного капитала экономического субъекта на современном этапе развития экономики. EUROPEAN RESEARCH. Сборник статей II Международной научно-практической конференции. Изд-во Наука и Просвещение. Пенза. 2016. С. 37-46.

17. Кыштымова Е.А. Методологические подходы к формированию учетно-аналитических подсистем для управления инвестированным капиталом предприятий.Фундаментальные исследования. - М.: ООО «Издательский дом «Академия естествознания». 2016. № 2-1. С. 169-174.

18. Лысюк Е.Ю., Тхаркахова И.Г. Резервный капитал в трактовке МСФО. Стратегические направления развития науки, образования, технологий. Сборник научных трудов по материалам международной научно-практической конференции. В 4-х частях / Под общей редакцией Ткачевой Е.П. Белгород: ООО «Агентство перспективных научных исследований». 2017. С. 86-89.

19. Наумова Е.А. Раскрытие в отчетности информации о конечных бенефициарах организации и ее аудиторское подтверждение. Актуальные проблемы учета, анализа и аудита: материалы X Юбилейной региональной научно-практической конференции. - СПб.: Изд-во СПбГМТУ, 2020. С. 72-77.

20. Поленова С.Н. Вопросы регулирования бухгалтерского учета нераспределенной прибыли. АудиTop. 2018. № 3. С. 27-33. 


\section{References}

1. Federal Law «On Accounting» No. 402-FZ of 06.12.2011. (ed. From 26.07.21 ). URL: http:// www.consultant.ru/document/cons_doc_LAW 122855/.

2. Federal Act No. 115-FZ of 07.08.2001 on Combating the Legalization (Laundering) of Proceeds of Crime and the Financing of Terrorism. (ed. From 02.07.2021). URL: http://www.consultant.ru/document/ cons doc LAW 32834/.

3. Decree of the Government of the Russian Federation dated 19.04.2021 No. 622 «On restrictions on the provision of information and documentation to an audit organization, to an individual auditor». URL: http:// www.consultant.ru/document/cons_doc_LAW_382679/.

4. Information message of the Ministry of Finance of Russia from 24.02.2021 No. IS-accounting-32 «Features of information disclosure in financial statements are established. URL: http://www.consultant.ru/document/ cons_doc_LAW_377859/.

5. International Financial Reporting Standard (IAS) 1 «Financial Reporting» (put into effect in the territory of the Russian Federation by Order of the Ministry of Finance of Russia dated 28.12.2015 No. 217n) (ed. from 05.08.2019). URL: http://www.consultant.ru/document/cons_doc_LAW_193588/.

6. International Audit Standard 705 (revised) «Modified Opinion in Audit Opinion» (put into effect in the Russian Federation by Order of the Ministry of Finance of Russia dated 09.01.2019 No. 2n ). URL: http:// www.consultant.ru/document/cons doc_LAW_317413/.

7. Regulations on accounting and accounting in the Russian Federation, clauses by order of the Ministry of Finance of the Russian Federation No. 34n from 29.07.1998. (ред. от 11.04.2018). URL: http:// http:// www.consultant.ru/document/cons doc LAW 20081/.

8. Accounting Regulations «Accounting Policy of the Organization», clauses Order of the Ministry of Finance of the Russian Federation No. 106n dated 06.10.2008 (PBU 1/2008) (ed. From 07.02.2020). URL: http:// www.consultant.ru/document/cons_doc_LAW 81164/.

9. Accounting Regulations «Accounting Statements of the Organization» RAS 4/99 (lb. by order of the Ministry of Finance of the Russian Federation No. 43n from 06.07.1999). (ed. From 08.11.2010, rev. from 29.01.2018). URL: http://www.consultant.ru/document/cons_doc_LAW_18609/.

10. Federal Accounting Standard «Fixed Assets», utv. by order of the Ministry of Finance of Russia dated 17.09.2020 No. 204n (FSBU 6/2020). URL: http://www.consultant.ru/document/cons_doc_LAW_365338.

11. On the forms of accounting statements of organizations, utv. By order of the Ministry of Finance of the Russian Federation No. 66n from 02.07.2010. (ред. от 19.04.2019). URL: http://www.consultant.ru/document/ cons_doc_LAW_103394/.

12. Procedure for determining the value of net assets, utv. By order of the Ministry of Finance of the Russian Federation No. 84n from 20.08.2014 (unit from 27.11.2020) . URL: http://www.consultant.ru/document/ cons_doc_LAW_169895/.

13. Evstafieva E. M. Theoretical aspects of the study of the definition of «Capital» from the point of view of the evolution of accounting, the economic journal «Bulletin of AGU». 2015. No. 3 (165).

14. Endovitsky E.A., Dokhina Yu.A. Economic essence and legal regulation of the capital of the organization. Socio-economic phenomena and processes. 2010. No. 5 (021). S. $12-16$.

15. Kanashevsky V.A. Concept of beneficial property in Russian judicial practice (private legal aspects ). Journal of Russian Law. 2016. No. 9 (237). S. 27-38.

16. T.N. Kurysheva Accounting for the equity of an economic entity at the present stage of economic development. EUROPEAN RESEARCH. Collection of articles of the II International Scientific and Practical Conference. Publishing House Science and Enlightenment. Penza. 2016. C. 37-46.

17. Kyshtymova E.A. Methodological approaches to the formation of accounting and analytical subsystems for managing the invested capital of enterprises. Fundamental Researchs. - Moscow: Publishing House Academy of Natural Sciences LLC. 2016. No. 2-1. S.169-174.

18. Lysyuk E.Yu., Tharkakhova I.G. Reserve capital in the interpretation of IFRS. Strategic directions for the development of science, education, technology. Collection of scientific works on the materials of the international scientific and practical conference. In 4 parts / Under the general editorship of Tkacheva E.P. - Belgorod: LLC Agency for Advanced Scientific Research. 2017. Pp. 86-89.

19. Naumova E.A. Disclosure of information about the final beneficiaries of the organization and its audit confirmation. Current problems of accounting, analysis and audit: materials of the X Anniversary Regional Scientific and Practical Conference. - St. Petersburg: Publishing House of St. Petersburg State Technical University, 2020. P. 72-77.

20. Polenova S.N. Issues of accounting of retained earnings. Auditor. 2018.No. 3. S .27-33. 